\title{
Genetic Variability Parameters for Yield and Yield Related Traits in Sesame (Sesamum indicum L.)
}

\author{
R. Kalaiyarasi ${ }^{1 *}$, K. Lokeshkumar ${ }^{2}$, M. Mohanraj ${ }^{2}$, \\ A. Priyadharshini ${ }^{2}$ and R. Rajasekar ${ }^{2}$
}

\author{
${ }^{1}$ Department of Genetics and Plant Breeding, TNAU, Coimbatore-641 003, India \\ ${ }^{2}$ Agricultural College and Research Institute (Tamil Nadu Agricultural University), \\ Kudumiyanmalai, Pudukkottai District-622 104, Tamilnadu, India
}

*Corresponding author

\section{A B S T R A C T}

The evaluation of phenotypic variability, heritability, genetic advance and diversity in germplasm collections is important for both plant breeders and germplasm curators to optimize the use of the variability available. In the present

\section{Keywords}

Sesame genotypes, GCV, PCV,

Heritability, Genetic advance

Article Info

Accepted:

07 July 2019

Available Online:

10 August 2019 study, Thirteen sesame genotypes were grown during Rabi Summer'2019 at Agricultural College and Research Institute, Kudumiyanmalai (TNAU) taken to assess genotypic, phenotypic variability and heritability coupled with genetic advance. The biometrical and morphological traits such as days to fifty percent flowering, plant height, number of branches, number of capsules per plant, seeds per capsule, thousand seed weight, seed yield per plant and plot yield. The GCV and PCV estimates were found to be high for seed yield per plant, number of capsules per plant and number of branches per plant. High heritability coupled with high genetic advance was observed for the characters seed yield per plant, number of seeds per capsule, number of capsules per plant, number of primary branches per plant and plant height. This indicated the additive genes governed these traits and the improvement could be brought about by selection for these traits. Therefore, these characters can be considered as a criterion for improving seed yield in breeding programs of sesame.

\section{Introduction}

Sesame (Sesamum indicum L.) is the oldest indigenous oil crops with longest history of its cultivation in India. India is still the world leader with maximum $(25.8 \%)$ production from the largest $(29.8 \%)$ area and highest export $(40 \%)$ of seeds of sesame. In India, sesame is being grown over an area of 16.67 lakh hectares with production of 6.57 lakh tonnes and productivity of $460 \mathrm{~kg} / \mathrm{ha}$ (Anon., 2014). It is cultivated extensively from tropical regions to the temperate zones in the world. It is fifth important edible oil crop in India after groundnut, rapeseed-mustard, sunflower and soybean. Sesame seed contains 
50\% oil, $23 \%$ protein and $15 \%$ carbohydrate (Ranganatha et al., 2012). The crop is highly tolerant to drought, grows well in most of the well-drained soils and various agro climatic regions, and is well adapted to different rotations. It can set seed and yield well under fairlyhigh temperature and can grow in stored soil moisture without rainfall and irrigation. Sesame oil has highest antioxidant content and contains several fatty acids such as oleic acid (43\%), linoleic acid (35\%), palmitic acid (11\%) and stearic acid (7\%). It has high commercial attributes by virtue of it being a rich source of quality edible oil enriched with proteins, vitamins, amino acids and antioxidants like sesamin, sesamolin and sesamol (Brar and Ahuja, 1979). Genetic variability is essential for continued genetic improvement of any crop species. Biometrical techniques to assess the genetic variability and the extent of heritability of the economic characters serve as a useful tool in evaluating the segregating population. These techniques will provide an insight into their magnitude of variability available in a crop and are effective in reducing the environmental effects substantially to project the real genetic effects with discrimination of better genotype from the rest. Yield is the resultant product of various morphological, physiological and biological components. To formulate an effective selection technique for increasing the yield, the association analysis among yield and yield contributing characters are important. The magnitude and direction of the association of yield components with yield will help us to programme our selection technique. Phenotypic and genotypic correlation coefficient and the yield components and their contribution in path analysis provide information on their relative importance in determining the yield (Dewey and $\mathrm{Lu}, 1959$ ). With this background, the present investigation is contemplated with the following objectives 1). To assess the variability parameters in the sesame genotypes. 2) To study the morphological, biometrical and leaf characters of the sesame genotypes.

\section{Materials and Methods}

The experimental materials for the present study involves thirteen sesame genotypes were selected including eleven advance sesame culture of Tamilnadu Agricultural University and two checks varieties TMV 7 and SVPR 1 (Table 1). The experiment was conducted in Agricultural College and Research Institute (Tamil Nadu Agricultural University), Kudumiyanmalai, Pudukkottai District of Tamil Nadu during Rabi Summer' 2019. The field experiment was conducted in a randomized block design with two replications. The eleven genotypes and two local checks were raised in a plot size of $4 \mathrm{~m} \mathrm{x}$ $0.3 \mathrm{~m} \mathrm{x} 4$ rows $\left(4.8 \mathrm{~m}^{2}\right)$. Seeds were sown on 29.01.2019 in ridges and furrows with a plant spacing of $30 \times 30 \mathrm{~cm}$. All agronomical practices like thinning, weeding was carried out at right time and irrigation was given at suitable interval. Five plants were randomly selected and biometrical observations were recorded on eight quantitative characters viz., days to fifty per cent flowering, plant height, number of branches per plant, number of capsules per plant, number of seeds per capsule, thousand seed weight $(\mathrm{gm})$, seed yield per plant (g) and plot yield (g). Observations on each character's contributed to the genetic diversity of the sesame genotypes were calculated using mean, variability, PCV and GCV, heritability and genetic advance for advanced cultures of sesame genotypes.

\section{Statistical analysis}

Phenotypic and genotypic co-efficient of variation ( $\mathrm{PCV}$ and $\mathrm{GCV}$ ) for each character were computed based on the methods given by Burton (1952). The co-efficient of variation 
was categorized as proposed by Sivasubramanian and Madhava Menon (1973). The heritability was computed based on the methods given by Lush (1949). The heritability per cent was categorized as suggested by Robinson et al., (1949). Genetic advance and genetic advance as percentage of mean were estimated according to the formula given by Johnson et al., (1955). Statistical analysis was done by using INDOSTAT software.

\section{Results and Discussion}

Mean performance of sesame genotypes for yield and yield related traits

The mean for days to fifty percent flowering ranged from 32 days to 39 days. Among the genotypes, COS 16007 have recorded the highest number of days to fifty percent flowering ranging to 39 days (Table 2.) Other genotypes were significantly on par with each other. The mean plant height of 13 sesame genotypes ranged from $96 \mathrm{~cm}$ (COS 16007) to $148 \mathrm{~cm}$ (COS 14001). Among the genotypes, COS 14001 recorded the highest plant height ranged upto $148 \mathrm{~cm}$. Among the parents, COS 14017 (W) had lowest number of branches (0) while SVPR1 CHECK recorded highest (8) number of branches.

Lowest number of capsules per plant observed in SVPR1 check (133) and highest in COS 13015 (W) (255.7) among 13 sesame genotypes (Table 2). Lowest number of seeds per capsules was observed in TMV7 (48.8) and highest in COS 13015 (W) (82) among 13 sesame genotypes. Lowest Thousand seed weight was observed in COS 14017(W), COS $16009(2.75 \mathrm{~g})$ and highest in TMV7 (3.85g) (Table 2). The seed yield per plant in parents ranged from $11 \mathrm{~g}$ (SVPR 1) to 21.68g (COS $14017 \mathrm{DW})$. The plot yield ranged from 229g [COS $13015(\mathrm{~W})]$ to $628 \mathrm{~g}$ [COS $13006(\mathrm{~W})]$. (Table 2).
Genetic variability for yield traits in sesame genotypes

In the present study, the highest phenotypic and genotypic variances recorded for the trait number of branches per plant and this was followed by the character single plant yield. The character days for fifty percent flowering have exhibited lowest phenotypic and genotypic variances. As the phenotypic and genotypic variances cannot be used for comparing the magnitude of variability directly, the coefficients of variation at phenotypic and genotypic levels have been used to compare the variability observed among the different characters. Since phenotypic and genotypic variances were associated with units of measurements, coefficient of variation was considered to make valid comparisons among the characters. The extent of variability measured by Phenotypic and genotypic co-efficient of variation provides information regarding the relative amount of variation for different characters. However it was not possible to assess the extent of heritable variance present in population. In this study, the GCV values were lower than PCV. In the present study, high GCV and PCV estimates were observed for seed yield per plant, number of capsules per plant, number of branches per plant. It was in accordance with the results obtained by Gidey et al., (2013) and Ismaila and Usman (2014) for number of capsules alone. High coefficient of variation for seed yield per plant was also recorded by Sumathi and Murlidharan (2010) and Parameshwarappa et al., (2009). Gangadhara et al., (2012) and Parameshwarappa et al., (2009) for seed yield/plant; Aristya et al., (2017), Saxena and Bisen, (2016), Desawi et al., (2014), Atul Singh et al., (2018) for number of capsules/plant; Mustafa et al., (2015), Rani (2014) for number of primary branches/plant and number of secondary branches/plant; Narayan and Murugan (2013) for number of seeds/capsule (Table 3). 
Table.1 List of sesame genotypes

\begin{tabular}{|c|c|}
\hline Sl. No. & Sesame Genotypes (11) \\
\hline 1 & COS - 13006 \\
\hline 2 & COS -13015 \\
\hline 3 & COS -14001 \\
\hline 4 & $\operatorname{COS}-14017(d w)$ \\
\hline 5 & COS -14017 (w) \\
\hline 6 & COS -14018 \\
\hline 7 & COS -14025 \\
\hline 8 & COS - 14026(b) \\
\hline 9 & $\operatorname{COS}-14026(w)$ \\
\hline 10 & COS -16007 \\
\hline \multirow[t]{2}{*}{11} & COS -16009 \\
\hline & Check Varieties (2) \\
\hline 12 & TMV 7(b) \\
\hline 13 & SVPR 1(w) \\
\hline & (w) - white; (dw) - dull white ; (b) Brown \\
\hline
\end{tabular}

Table.2 Mean performance of yield and yield related traits of sesame genotypes

\begin{tabular}{|c|c|c|c|c|c|c|c|c|}
\hline Genotype & $\begin{array}{l}\text { Days to } \\
50 \% \\
\text { flowerin } \\
\quad \mathrm{g}\end{array}$ & $\begin{array}{l}\text { Plant } \\
\text { height } \\
(\mathbf{c m})\end{array}$ & $\begin{array}{c}\begin{array}{c}\text { Number } \\
\text { of } \\
\text { branches }\end{array} \\
\text { per plant }\end{array}$ & $\begin{array}{l}\text { Number } \\
\text { of } \\
\text { capsules } \\
\text { per plant }\end{array}$ & $\begin{array}{c}\text { Number } \\
\text { of seeds } \\
\text { per } \\
\text { capsule }\end{array}$ & $\begin{array}{c}1000 \\
\text { Seed } \\
\text { weight } \\
(\mathrm{g})\end{array}$ & $\begin{array}{c}\text { Seed } \\
\text { yield per } \\
\text { plant } \\
\text { (g) }\end{array}$ & $\begin{array}{c}\text { Plot } \\
\text { yield } \\
\text { (g) }\end{array}$ \\
\hline COS13006(W) & 38.0 & 133.5 & 4.0 & 180.0 & 74.0 & 3.40 & 20.2 & 628.0 \\
\hline $\operatorname{COS13015}(\mathrm{W})$ & 38.0 & 122.0 & 4.0 & 254.0 & 82.0 & 3.52 & 20.3 & 605.0 \\
\hline COS14026(B) & 38.0 & 108.0 & 4.0 & 159.0 & 71.8 & 3.10 & 16.0 & 426.5 \\
\hline $\operatorname{CoS14017(W)}$ & 35.0 & 126.0 & 1.0 & 165.0 & 74.5 & 2.75 & 20.8 & 551.0 \\
\hline COS14017(DW) & 35.0 & 125.5 & 6.5 & 148.5 & 74.4 & 3.15 & 21.7 & 574.0 \\
\hline COS14018 & 32.0 & 135.2 & 4.5 & 168.0 & 67.8 & 3.35 & 20.7 & 615.0 \\
\hline COS14025 & 37.0 & 141.6 & 6.0 & 199.5 & 65.1 & 3.52 & 20.9 & 571.0 \\
\hline $\operatorname{COS14026}(W)$ & 37.0 & 100.0 & 2.5 & 152.0 & 74.0 & 2.85 & 14.3 & 532.5 \\
\hline COS16007 & 38.5 & 97.0 & 5.5 & 179.0 & 64.0 & 3.41 & 13.8 & 574.0 \\
\hline COS16009 & 35.5 & 133.0 & 5.0 & 221.0 & 64.8 & 2.75 & 13.1 & 552.0 \\
\hline COS14001 & 35.0 & 146.5 & 6.0 & 241.0 & 65.5 & 3.55 & 17.4 & 514.0 \\
\hline TMV 7 & 38.0 & 121.5 & 7.0 & 155.0 & 48.9 & 3.85 & 11.7 & 541.0 \\
\hline SVPR 1 & 38.0 & 105.5 & 7.5 & 132.5 & 66.4 & 2.90 & 11.1 & 529.0 \\
\hline
\end{tabular}


Table.3 Parameters of genetic variability for yield and yield related traits in sesame genotypes

\begin{tabular}{|l|c|c|c|c|c|}
\hline \multicolumn{1}{|c|}{ Characters } & $\begin{array}{c}\text { PCV } \\
(\boldsymbol{\%})\end{array}$ & $\begin{array}{c}\text { GCV } \\
(\boldsymbol{\%})\end{array}$ & $\begin{array}{c}\text { ECV } \\
(\boldsymbol{\%})\end{array}$ & $\begin{array}{c}\text { Heritability } \\
\mathbf{h}^{\mathbf{2}} \mathbf{( \% )}\end{array}$ & $\begin{array}{c}\text { GA as (\%) } \\
\text { of Mean }(\mathbf{5 \% )}\end{array}$ \\
\hline Days to fifty per cent flowering & 5.206 & 4.86 & 1.852 & 87.3 & $\mathbf{9 . 3 6}$ \\
\hline Plant height & 13.12 & 13.02 & 1.575 & 98.6 & $\mathbf{2 6 . 6 4}$ \\
\hline Number of branches per plant & 47.63 & 44.73 & 16.365 & 88.2 & $\mathbf{8 6 . 5 4}$ \\
\hline Number of capsules per plant & 20.86 & 20.49 & 3.899 & 96.5 & $\mathbf{4 1 . 4 7}$ \\
\hline Number of seeds per capsule & 11.63 & 11.62 & 0.937 & 99.4 & $\mathbf{2 3 . 8 7}$ \\
\hline Thousand seed weight & 10.95 & 10.66 & 2.497 & 94.8 & $\mathbf{2 1 . 3 9}$ \\
\hline Seed yield per plant & 22.95 & 22.84 & 2.209 & 99.1 & $\mathbf{4 6 . 8 4}$ \\
\hline Plot yield & $\mathbf{8 . 9 0 8}$ & $\mathbf{8 . 6 5}$ & $\mathbf{2 . 0 9 1}$ & $\mathbf{9 4 . 5}$ & $\mathbf{1 7 . 3 4}$ \\
\hline
\end{tabular}

Classes of Heritability (\%): High >60\%, Medium 30-60\%, Low < $30 \%$

Classes of Genetic Advance (\%): High >20\%, Medium 10-20\%, Low $<10 \%$

It indicated that there was greater diversity for these traits in sesame. Hence, direct selection based on these traits would be effective for the improvement of this crop. The PCV and GCV values for 1000 seed weight were medium. Days to maturity had low PCV and GCV estimates indicating low scope of selection for improvement. Similar results were obtained for Gidey et al., (2013). Estimation of genotypic coefficient of variation gives the extent of variability present in the population, but the genotypic coefficient of variation alone does not give the heritable variation present in the population. Hence, heritability and genetic advance, the important selection parameters were worked out which help in understanding the mode of inheritance of quantitative traits. Relative comparison of heritability estimates and genetic advance as per cent of mean would give an idea about the nature of gene action governing a particular character. The estimates of heritability help the plant breeder in selection of elite genotypes from diverse populations. In the present study, high heritability was observed for the characters seed yield per plant, number of branches per plant, plant height, number of capsules per plant and seeds per capsule which was in accordance with the results obtained by Gidey et al., (2013) and Ismaila and Usman (2014) for number of capsules alone. This indicates that selection for these characters would give the best results for selecting sesame genotypes with these traits with high heritability. Similarly high genetic advance as percentage of mean was observed in seed yield per plant and number of branches per plant, which was similar with the results obtained by Gidey et al., (2013) and Menzir (2012) for seed yield per plant alone. But low genetic advance as percentage of mean was observed in case of days for fifty percent flowering. High heritability coupled with high genetic advance was observed for the characters seed yield per plant, number of seeds per capsule, number of capsules per plant, number of branches per plant, plant height. This showed that these characters were controlled by additive gene action and revealed better scope for improvement of these characters through direct selection.

\section{References}

Anonymous, 2014. Ministry of Agriculture, Govt. of India. www.nmoop.gov.in.

Aristya VE, Taryono and Wulandari. 2017. Genetic variability, standardized multiple linear regression and principal component analysis to determine some important sesame yield components 
AGRIVITA Journal of Agricultural Science. 39(1): 83-90.

Atul Singh, Rajani Bisen and AkankshaTiwari. 2018. Genetic Variability and Character Association in Sesame (Sesamum indicum L.) Genotypes. Int.J.Curr. Microbiol. App.Sci., 7(11): 2407-2415.

Brar, G. and Ahuja, K.1979. Sesame: its culture, genetics, breeding and biochemistry. Annual reviews of plant sciences. Pp. 245- 313.

Burton, GW 1952. Quantitative Inheritance in grasses. Proc. Sixth Inter. Grassland Cong., 1: 277-283

Desawi HT, Sentayehu AK, and Daniel EG. 2014. Assessment of genetic variability, genetic advance, correlation and path analysis for morphological traits in sesame genotypes. Asian Journal of Agricultural Research 8(4): 181-197.

Dewey, DH and Lu, KH. 1959. A correlation and path coefficient analysis of components of crested wheat grass seed production. Agron. J., 51: 515-518.

Gangadhara K, Chandra P, Bharamaraj B, Shadakshari TV, Yathish KR and Rajesh AM. 2012. Genetic divergence, genetic advance and heritability in sesame (Sesamum indicum L.). Bioinfolet 9 (4): 457-462.

Gidey, Y.T., Kebede SA and Gashawbeza GT. 2013 Assessment of genetic variability, genetic advance correlation and path analysis for morphological traits in sesame genotypes. Intl. J. Plant Breed. Gent., 7(1): 21-34.

Ismaila A and Usman A. 2014. Genetic variability for yield and yield components in sesame (Sesamum indicum L.). International Journal of Science and Research 3(9): 63-66.

Johnson HW, Robinson HF and Comstock RE. 1955. Genotypic, phenotypic correlations in soybean and their implication in selection. Agronomy
Journal 47: 477- 483.

Lush. JL (1949). Heritability Of Quantitative Characters In Farm Animals. Proc. VlJ. Int. Congo Genet. Suppl. Heriditas, 36: 356-375.

Menzir, A.2012. Phenotypic variability, divergence analysis and heritability of characters in sesame (Sesamum indicum L.) genotypes. Nat. Sci., 10(10):117126.

Mustafa HSB, Hasan EU, Qurban Ali Q, Anwar M, Aftab M and Mahmood T. 2015. Selection criteria for improvement in sesame (Sesamum indicum L.). American Journal of Experimental Agriculture 9(4): 1-13.

Narayan R and Murgan S. 2013. Studies on variability in sesame (Sesamum indicum L.). International Journal of Agricultural Research 2 (11): 52-55.

Parameshwarappa, S.G., Palakshappa MG, Salimath PM and Parameshwarappa. KG. 2009. Evaluation and characterization of germplasm accessions of sesame (Sesamum indicum L.). Karnataka J. Agric. Sci., 22(5): 1084-1086.

Ranganatha ARG, Lokesha R, Tripathi A, Tabassum Aasfa, Paroha $S$ and Shrivastava MK. 2012. Sesame improvement-Present status and future strategies. Journal of Oilseeds Research 29(1): 1-26.

Rani PJ. 2014. Variability, heritability and genetic advance of yield and yield attributing traits over different environments in Sesamum (Sesamum indicum L.). Trends in Biosciences 7(17): 2402-2404

Robinson, HF, Comstock, RE and Harvey. PH. 1949. Estimation of heritability and the degree of dominance in corn. J. Agron., 41: 353-359.

Saxena K and Bisen R. 2016. Genetic variability correlation and path analysis studies for yield and yield component 
traits in Sesamum (Sesamum indicum L.). International Journal of Agriculture Sciences 8 (61): 3487-3489.

Sivasubramanian, S and Madhava Menon, P. 1973. Genotypic and phenotypic variability in rice. Madras Agri. Journal., 60: 1093-1096.
Sumathi, P. and V. Murlidharan. 2010. Analysis of genetic variability, association and path analysis in the hybrids of sesame (Sesamum indicum L.). Tropical Agricultural Research and Extension, 13(3): 63-67.

\section{How to cite this article:}

Kalaiyarasi, R., K. Lokeshkumar, M. Mohanraj, A. Priyadharshini and Rajasekar, R. 2019. Genetic Variability Parameters for Yield and Yield Related Traits in Sesame (Sesamum indicum L.). Int.J.Curr.Microbiol.App.Sci. 8(08): 819-825.

doi: https://doi.org/10.20546/ijcmas.2019.808.093 